http://journal.uinsgd.ac.id/index.php/biodjati

\title{
THE DIVERSITY AND DIAMETER GROWTH RATE OF SPROUTING-TYPE TREE IN BUKIT PINANG-PINANG FOREST PERMANENT PLOTS
}

\author{
Ade Ayu Oksari' ${ }^{1}$ Irvan Fadli Wanda*2, Erizal Mukhtar ${ }^{3}$, Chairul $^{3}$
}

Received : May 27, 2019

Accepted : September 24, 2019

DOI: 10.15575/biodjati.v4i2.4728

${ }^{1}$ Department of Biology, Faculty of Mathematics and Natural Sciences, Nusa Bangsa

Jl. KH. Sholeh Iskandar Km 4, Bogor 16166, West Java, Indonesia.

${ }^{2}$ Research Center for Plant Conservation and Botanic Gardens (Bogor Botanic Gardens), Indonesian Institute of Sciences, Jl. Ir. H. Juanda No. 13, Bogor 16122, West Java, Indonesia ${ }^{3}$ Department of Biology, Faculty of Mathematics and Natural Sciences, Universitas Andalas, Padang

J1. Universitas Andalas, Limau Manis, Kec. Pauh, Padang 25163, West Sumatera, Indonesia

e-mail:

1adeayuoksari@gmail.com

*2ivan.wandassi@gmail.com

3erizal@fmipa.unand.ac.id

*Corresponding author

\begin{abstract}
The process of forest regeneration can take place within a certain period of time. Sprouting is a form of strategy for in adapting to its environment for success in regenerating. The Research on the diversity and diameter growth rate of sprouting-type tree in Bukit Pinangpinang forest permanent plots, West Sumatra was carried out from October 2012 to December 2016 in the forest of Bukit Pinang-Pinang, West Sumatra and Herbarium Department of Biology, Universitas Andalas, Padang. This research was conducted using a survey method by census. The parameters analyzed were plant species composition, Morishita Index, Mann-Whitney test, Regression and Correlation test as well as RDGR (Relative Diameter of Growth Rate). The result of experiment was found 40 species of trees sprouting type in forest permanent plot Bukit Pinang-Pinang. The pattern of sprouting type trees distribution in the study locations was found to have a clustered, random and uniform pattern. Relative Diameter Growth Rate (RDGR) of 40 sprouting types of trees in the Bukit Pinang-Pinang forest permanent plots ranged from $0.003 \mathrm{~cm} / \mathrm{cm} /$ year to $0.0288 \mathrm{~cm} / \mathrm{cm} /$ year. Altitude did not affect RDGR of an individual tree sprouting type for 31 years.
\end{abstract} Keywords: Bukit Pinang-pinang Forest, sprouting-type diversity, $R D G R$

\section{Citation}

Oksari, A. A., Wanda, I. F., Mukhtar, E. \& Chairul. (2019). The Diversity and Diameter Growth Rate of Sproutin-Type in Bukit Pinang-Pinang Forest Permanent Plots. Jurnal Biodjati, 4(2), 184193

\section{INTRODUCTION}

Indonesia's natural forests continue to be damaged. Nationally, the estimated damage of forests each year is about 1.6 to 2.3 million hectares. The forest destruction has caused the critical area of protected forests and conservation, which has now reached 8.1 million hectares and 27.7 million hectares of production forest (Kartodihardjo, 2001). The process of forest regeneration takes place within a certain period of time. Naturally, forest regeneration is the process that established after forest trees have been harvested or have died from fire, insects, or disease. A barren forest needs 50 to 500 years to be restored to the original form (Kardiman, 2011).

Sprouting-type tree through stem shoots 


\section{JURNAL BIDDJATI}

http://journal.uinsgd.ac.id/index.php/biodjati

and branching shoots has an important ability for a plant to repair damage due to interference (Halle et al., 1978). Sprouting is a form of plant strategy in adapting to its environment for regeneration (Bond \& Midgley, 2001; Rasnovi, 2006). The regeneration ability of a plant was strongly affected by the ability in seedlings and bud stem (sprouting). The studies about plant regeneration ability with tree saplings have been extensively conducted while diversity and diameter growth rate studies of the sprout-type trees have not been done.

The relationship between productivity (such as diameter growth rate) and species diversity is often positively correlated (Whittaker \& Heegaard, 2003; Balvanera et al., 2006; Gillman \& Wright, 2006). The diversity in ecology is generally meant as the species diversity determined by integrating the number of species in the community and the relative abundance of each species (McNaughton $\&$ Wolf, 1990). This is important to determine the effectiveness of regenerating species with type-sprouting. Regeneration in the woods by sprouting had an important role in restoring biomass that was lost due to a disturbance in the forest (Mukhtar et al., 2012).

Several studies on forest regeneration through sprouting have been conducted. Based on research by Mukhtar et al. (2012), the dominant species that have great ability in regeneration through stem bud in Ulu Gadut tropical forest were Villebrunia rubescens, Litsea lanceolata and Pternandra sp. Nishimura et al. (2010) stated that if the rate of a species growth was high, the ability to regenerate by sprouting would be low which can be seen from the average sprouting proportion from Lithocarpus species $(23.5 \%)$ that was higher than other Quercus $(3.8 \%)$ in the tree stages. Although several studies on forest regeneration through sprouting have been conducted, they focused on the region or the tem- perate coniferous forests, not tropical forests (Mukhtar et al., 2012). It caused the research on forest regeneration through sprouting in Indonesia needs to be conducted, including in Pinang-Pinang Forest.

Bukit Pinang-Pinang Forest Permanent Plots is a tropical low land forest located in West Sumatra, Indonesia. In this area, there was a hectare plot for ecological studies that have been designed at the foot of Mount Gadut Padang by Hotta and Ogino in 1981 (Hotta, 1984). Most of the tree stands in the Bukit Pinang-Pinang forest are almost intact, but in some areas, especially at the foothill has been destroyed. Some of them have been cultivated and they have taken the timber for building materials. This activity took place continuously and widely spread (Rofiadi, 1999). For this reason, it is necessary to conduct research on the regeneration by sprouting-type trees before the trees in this area are threatened.

Ashish et al. (2010) stated that the diameter of the trunk of a tree stump on the type of Rhododendron arboreum with sprouting intensity had a negative correlation ( $\mathrm{r}=$ $-0.759, p<0.001)$. It means that the intensity of sprouting affected by the diameter of trunk a tree stump. It would provide an overview of the growth rate of trees during a particular decade. The growth rate of a sprouting type of tree species will be associated with the stability of a forest structure and the resources stored underground (Schwilk \& Ackerly, 2005). Research on the increase in stem diameter in Bukit Pinang-Pinang Forest Permanent Plots has been carried out. However, studies on diversity and increasing stem diameter based on sprouting-type tree have not been carried out. Therefore, research about diversity and quantify the diameter growth rate of trees that have a type of stem buds (sprouting-type) in Bukit Pinang-Pinang Forest Permanent Plots for three decades need to be conducted. The 
Jurnal Biodjati 4(2):184-193, November 2019

\section{JURNAL BIDDJATI}

http://journal.uinsgd.ac.id/index.php/biodjati

purpose of the study was to determine the diversity and the increase in diameter trunk of sprouting types in Bukit Pinang-Pinang Forest for three decades as wel as to determine the correlation of the increase in diameter with topography.

\section{MATERIALS AND METHODS}

\section{Study Site}

The research site was in Bukit PinangPinang Forest Permanent Plots, West Sumatra and Herbarium Department of Biology, Universitas Andalas, Padang. Pinang-Pinang Forest which is lowland tropical rain forests is located in the area of Gadut Mount. This hill is adjacent to the Kambut hills in the north, the south by the Gadut River, the west by the
Inaugurates hill and the east by the Gambir hill (Figure 1). Its topography is undulating to mountainous areas. It is a natural forest physically as secondary forest (Ogino et al., 1984). Pinang-Pinang forest has a high rainfall of over $5000 \mathrm{~mm}$ and nothing was found dry season (Hotta, 1984). Based on data at 1981, 852 trees were found on permanent plot in the forest of Bukit Pinang-Pinang. A survey conducted in the field revealed that the trees have been survived from 1981 until 2012 (with the same number of trees) that was 355 trees. It was found that 127 trees were potentially sprouting-type trees and 227 trees were possibly non-sprouting.Fertilization is carried out at the beginning of planting. This process is carried out by removing weeds that grow around the plant as well as controlling. pest and disease.

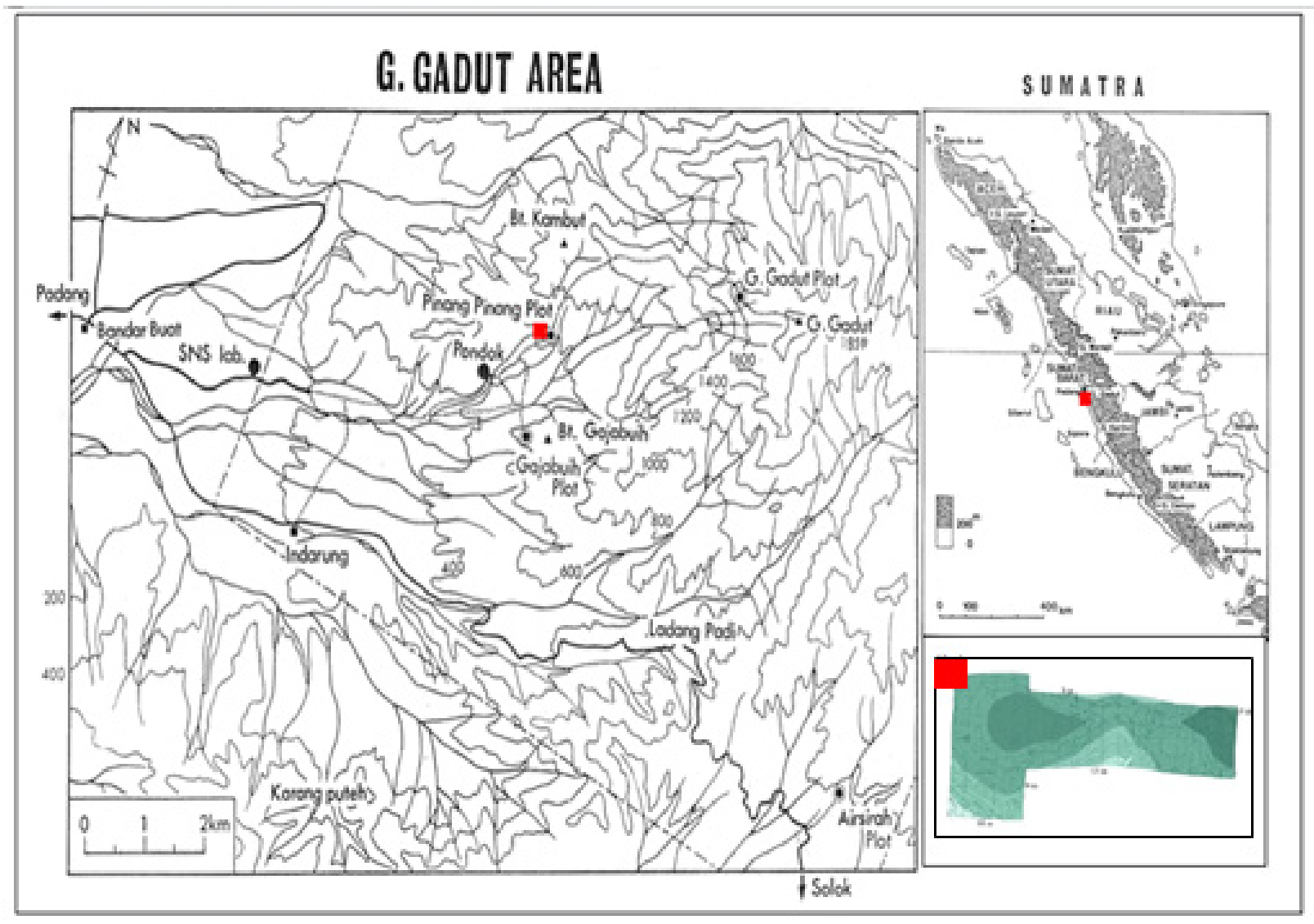

Figure 1. The map of research location (Hotta, 1984) and permanent plots in Pinang-Pinang Hill Forest. Description: The difference of each contour line is 2 meters. 


\section{JURNAL BIDDJATI}

http://journal.uinsgd.ac.id/index.php/biodjati

\section{Methods}

The method was survey by census. This study was conducted from October 2012 to December 2016 at 1 ha Pinang-Pinang permanent plot with 115 sub-plot. Each subplot was observed and measured its DBH in all of the trees that refers to the permanent forest plot data Bukit Pinang-Pinang forest Permanent Plots in 1981. Observations included all the individual trees that exist in the research area (fall/die) and individual tree types sprouting. Then, the types sprouting which has been obtained would be adapted to the data of Elias (unpublished), Yoneda (unpublished), Nishimura et al. (2010), Delmy (1998), and Kiyono \& Hastaniah (2005).

\section{Data Analysis}

Plants found were identified in the Herbarium Universitas Andalas, grouped by species and family. Analysis of the composition of vegetation was carried out by calculating important value index, Morishita Index and Relative Diameter of Growth Rate (RDGR). The important value index (INP) formula is: $\mathrm{INP}=\mathrm{FR}+\mathrm{DR}$, where: $\mathrm{KR}=$ Relative density $(\%)$ and $\mathrm{DR}=$ dominance Relative $(\%)$. Distribution of sprouting types of trees was analyzed using the Morishita Index as follows (Brower and Zar, 1977):

$$
i d=n \frac{\sum X^{2}-N}{N(N-1)}
$$

Description; $i d=$ Morishita Index; $\mathrm{n}=$ Number of plots; $\mathrm{N}=$ Total number of individuals in total $\mathrm{n}$ plots and $\Sigma \mathrm{X}^{2}=$ The square of the number of individuals per plot for a total of $\mathrm{n}$ plots.

RDGR analyzed using the formula (Hunt, 1990):

$$
\mathrm{RDGR}=\frac{\log \mathrm{D} 2-\log \mathrm{D} 1}{\Delta \mathrm{t}}
$$

Oksari et al.
Description; RDGR $=$ Relative Diameter Growth Rate $(\mathrm{cm} / \mathrm{cm} / \mathrm{yr}) ; \mathrm{D} 2=\mathrm{DBH}$ in $2012(\mathrm{~cm}) ; \mathrm{D} 1=\mathrm{DBH}$ $1981(\mathrm{~cm})$ and $\Delta \mathrm{t}=$ Difference in years $(\mathrm{yr})$

RDGR individual types of trees sprouting from each type were averaged. Furthermore, the results of this average will show RDGR of each type of tree species sprouting. RDGR of each tree would be grouped based on the height of the topography in Bukit Pinang-Pinang Forest.

The data obtained from the altitude with RDGR will be tested with the Mann-Whitney using the PASS program (Programs in Analytics and Statistics Studies).

\section{RESULTS AND DISCUSSION}

\section{Composition and Distribution of Tree Sprouting Types}

The composition of sprouting trees in the permanent Bukit Pinang-Pinang forest plot consists of 19 families, 29 genera, 40 species and 188 individuals. Fagaceae is the main family with 3 genus, 11 species and 23 individuals. A more detailed description presented in Table 1.

The Fagaceae were the most common family among sprouting tree species and regeneration strategy of the family byrecover faster than others. According to Lewis \& Clark (2011) the ability of plants to carry out recovery through sprouting will be able to overcome this type of interference. Furthermore, according to Vesk \& Westoby (2004) the ability of sprout in the face of the interference threat will also be able to overcome these types conditions both natural disturbances and disruption of human activities.

The pattern of sprouting type trees distribution in the study locations was found to have a clustered, random and uniform pattern. The pattern of uniform distribution $(\mathrm{Id}<1)$ was 


\section{JURNAL BIDDJATI}

http://journal.uinsgd.ac.id/index.php/biodjati

found in 9 species namely Lithocarpus urceolaris, Litsea lanceolata, Litsea sp, Lithocarpus lucidus, Barringtonia sp., Pometia alnifolia, Aporusa frutescens, Lithocarpus ewyckii and Lithocarpus crassinervius. Furthermore the clustered distribution pattern ( $\mathrm{Id}>1)$ was found in 6 species namely Eurya acuminata, Syzygium sp., Mallotus subpeltatus, Lithocarpus meijeri, Canarium sp. and Durio griffithii. The next distribution pattern was random
$(\mathrm{Id}=1)$ that found in the majority of sprouting types (25 speciess). The results showed that sprouting types have specific habitats where they can grow and develop. According to Poorter et al. (2010) who found that the type of tree shade tolerance species (species like shade) has more ability for sprouting compared to the type of light-demanding tree species (species that like full light).

Table 1. Composition of sprouting trees in the permanent Bukit Pinang-Pinang forest plot

\begin{tabular}{|c|c|c|c|c|c|c|}
\hline No & Family & Genus & Species & $\begin{array}{c}\text { Total } \\
\text { Specimen }\end{array}$ & $\operatorname{INP}(\%)$ & Id \\
\hline \multirow{7}{*}{1} & \multirow{7}{*}{ Theaceae } & Eurya & Eurya acuminata ${ }^{a}$ & 3 & 1.772 & 1,167 \\
\hline & & Schima & Schima wallichii ${ }^{e}$ & 3 & 2.854 & 1 \\
\hline & & \multirow{2}{*}{ Quercus } & Quercus argentata $^{c}$ & 3 & 4.250 & 1 \\
\hline & & & Quercus oidocarpa ${ }^{c}$ & 2 & 1.337 & 1 \\
\hline & & \multirow[t]{3}{*}{ Lithocarpus } & Lithocarpus javensis $^{c}$ & 4 & 4.314 & 1 \\
\hline & & & Lithocarpus urceolaris $^{c}$ & 1 & 0.903 & 0 \\
\hline & & & Lithocarpus lucidus ${ }^{c}$ & 1 & 1.309 & 0 \\
\hline \multirow[t]{7}{*}{2} & \multirow[t]{7}{*}{ Fagaceae } & & Lithocarpus meijeri $^{c}$ & 3 & 4.928 & 1,167 \\
\hline & & & Lithocarpus luteus $^{c}$ & 2 & 1.334 & 1 \\
\hline & & & Lithocarpus ewyckii ${ }^{c}$ & 1 & 0.476 & 0 \\
\hline & & & Lithocarpus crassinervius $^{c}$ & 1 & 2.105 & 0 \\
\hline & & & Castanopsis sp. ${ }^{c}$ & 3 & 1.713 & 1 \\
\hline & & Castanopsis & Castanopsis rhamnifolia ${ }^{c}$ & 2 & 2.046 & 1 \\
\hline & & Macaranga & Macaranga hullettii ${ }^{f}$ & 2 & 1.012 & 1 \\
\hline \multirow{3}{*}{3} & \multirow{3}{*}{ Euphorbiaceae } & Claoxylon & Claoxylon sp. ${ }^{f}$ & 4 & 2.239 & 1 \\
\hline & & Mallotus & Mallotus subpeltatus $^{f}$ & 7 & 3.359 & 1,133 \\
\hline & & Aporusa & Aporusa frutescens ${ }^{f}$ & 1 & 0.496 & 0 \\
\hline \multirow[t]{2}{*}{4} & \multirow[t]{2}{*}{ Dipterocarpaceae } & Shorea & Shorea maxwelliana ${ }^{a}$ & 14 & 7.037 & 1 \\
\hline & & Beilschmiedia & Beilschmiedia bangkae $^{b}$ & 2 & 1.130 & 1 \\
\hline \multirow[t]{2}{*}{5} & \multirow[t]{2}{*}{ Lauraceae } & \multirow[t]{2}{*}{ Litsea } & Litsea lanceolata ${ }^{a}$ & 1 & 0.524 & 0 \\
\hline & & & Litsea sp. $^{a}$ & 2 & 0.992 & 0 \\
\hline 6 & Myrtaceae & Syzygium & Syzygium sp. ${ }^{a}$ & 18 & 13.669 & 1,052 \\
\hline \multirow[t]{3}{*}{7} & \multirow[t]{3}{*}{ Sapindaceae } & \multirow[t]{2}{*}{ Nephelium } & Nephelium juglandifolium $^{a}$ & 15 & 15.297 & 1 \\
\hline & & & Nephelium sp. ${ }^{b}$ & 4 & 2.494 & 1 \\
\hline & & Pometia & Pometia alnifolia ${ }^{d}$ & 1 & 0.496 & 0 \\
\hline 8 & Melastomataceae & Pternandra & Pternandra coerulescens $f$ & 4 & 2.082 & 1 \\
\hline \multirow[t]{3}{*}{9} & \multirow[t]{3}{*}{ Sapotaceae } & Palaquium & Palaquium dasyphyllum ${ }^{f}$ & 4 & 2.079 & 1 \\
\hline & & & Palaquium hexandrum ${ }^{f}$ & 4 & 2.189 & 1 \\
\hline & & Madhuca & Madhuca sp. ${ }^{f}$ & 5 & 2.647 & 1 \\
\hline \multirow{2}{*}{10} & \multirow{2}{*}{ Meliaceae } & Dysoxylum & Dysoxylum sp. ${ }^{f}$ & 9 & 4.965 & 1 \\
\hline & & Sandoricum & Sandoricum koetjape $f$ & 5 & 2.501 & 1 \\
\hline 11 & Myristicaceae & Knema & Knema cinerea ${ }^{f}$ & 2 & 0.942 & 1 \\
\hline 12 & Thymelaeaceae & Gonystylus & Gonystylus forbesii $^{f}$ & 8 & 4.042 & 1 \\
\hline 13 & Lecythidaceae & Barringtonia & Barringtonia sp. ${ }^{a}$ & 1 & 0.575 & 0 \\
\hline 14 & Polygalaceae & Xanthophyllum & Xanthophyllum rufum ${ }^{a}$ & 2 & 0.956 & 1 \\
\hline 15 & Burseraceae & Canarium & Canarium sp. ${ }^{a}$ & 6 & 6.207 & 1,133 \\
\hline 16 & Bombacaceae & Durio & Durio griffithii ${ }^{a}$ & 7 & 3.995 & 1,119 \\
\hline 17 & Malvaceae & Sterculia & Sterculia cuspidata ${ }^{f}$ & 4 & 2.082 & 1 \\
\hline 18 & Moraceae & Ficus & Ficus sp. ${ }^{a}$ & 4 & 1.978 & 1 \\
\hline 19 & Ebenaceae & Diospyros & Diospyros diepenhorstii ${ }^{f}$ & 3 & 1.446 & 1 \\
\hline
\end{tabular}




\section{JURNAL BIDDJATI}

http://journal.uinsgd.ac.id/index.php/biodjati

\section{Relative Diameter Growth Rate (RDGR)}

The RDGR of 40 species of sprouting type trees in forest permanent plot PinangPinang Hills were range between $0.003 \mathrm{~cm} /$ $\mathrm{cm} /$ year to $0.0288 \mathrm{~cm} / \mathrm{cm} /$ year. The more complete description presented in Figure 2.

Figure 2 showed that Quercus argentata (Fagaceae) had the highest RDGR value while Diospyros diepenhorstii (Ebenaceae) had the lowest RDGR. Families Fagaceae dominated sprouting species that had the highest RDGR values, but among these types had their own character. According to Nishimura et al. (2010) stated that the average sprouting proportion of the Lithocarpus spp (23.5\%) was higher than Quercus spp (3.8\%). Quercus had more seedlings while Lithocarpus showed varied distribution.

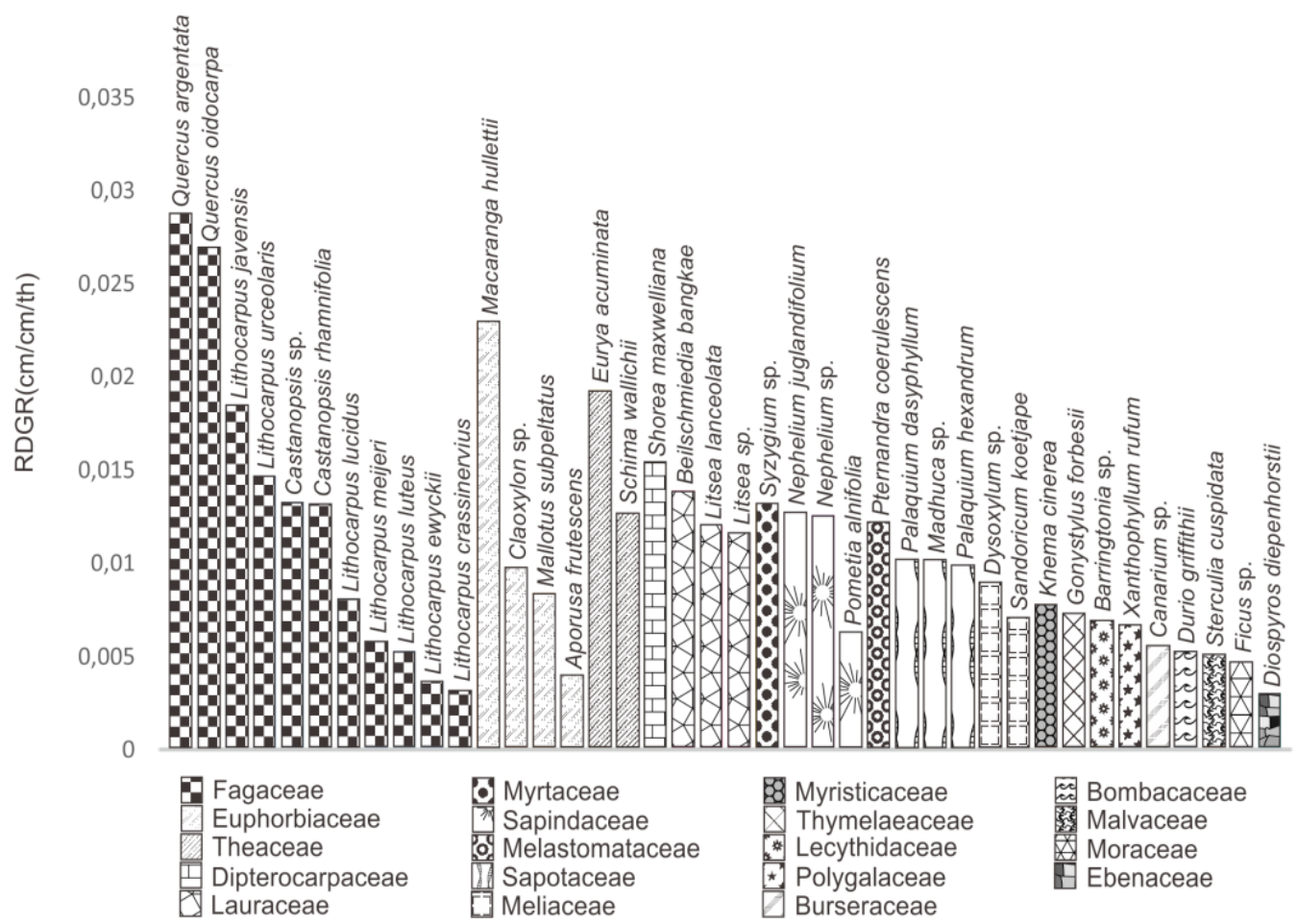

Figure 2. RDGR of 19 families of sprouting type in Pinang-Pinang Hill Forest

Individuals sprouting had slower growth because they had to make the canopy back and supported a large root system, so they were not able to allocate resources to enlarge the diameter (Putz \& Sharitz, 1991). Furthermore, according to Nishimura et al. (2010), if the growth rate of species was high, the ability to regenerate by sprouting would be low.

The high RDGR value of Quercus argentata also could be caused the sprouting was "single-stemmed" while Diospyros diepenhorstii was "multi-stemmed". According to Giudici \& Zingg (2005), a "mulOksari et al. ti-stemmed" and short sprouting tend to be shaded by a "single-stemmed" sprouting and their non-sprouting competitors, so the allocation was fixed only on areas that have the disorder or unproductive. Furthermore, according to Bellingham \& Sparrow (2009), multi-stemmed could only achieve subcanopy layer of a forest stands. The similar case was also found in the study that Diospyros diepenhorstii that only achieved the sub-canopy layer. Macaranga hulletii was a pioneer species that also had the highest RDGR values among other species in the family Euphor- 


\section{JURNAL BIDDJATI}

http://journal.uinsgd.ac.id/index.php/biodjati

biaceae. According to Bond (1994), sprouting was more resistant to disturbances that could tolerate the formation of plant that needs a long period and would tend to preserve their genetic diversity. Irawan \& Gruber (2004) found that the same type on Eusideroxylon zwageri (Lauraceae) in which a portion sprouting growth in diameter have high growth faster than the seedlings without sprouting.

\section{Relative Diameter Growth Rate (RDGR) by Topography}

RDGR showed differences based on tree-growth location. It could be based on habitat and height of the growth. Figure 3 depicted RDGR reviewed based on topography.

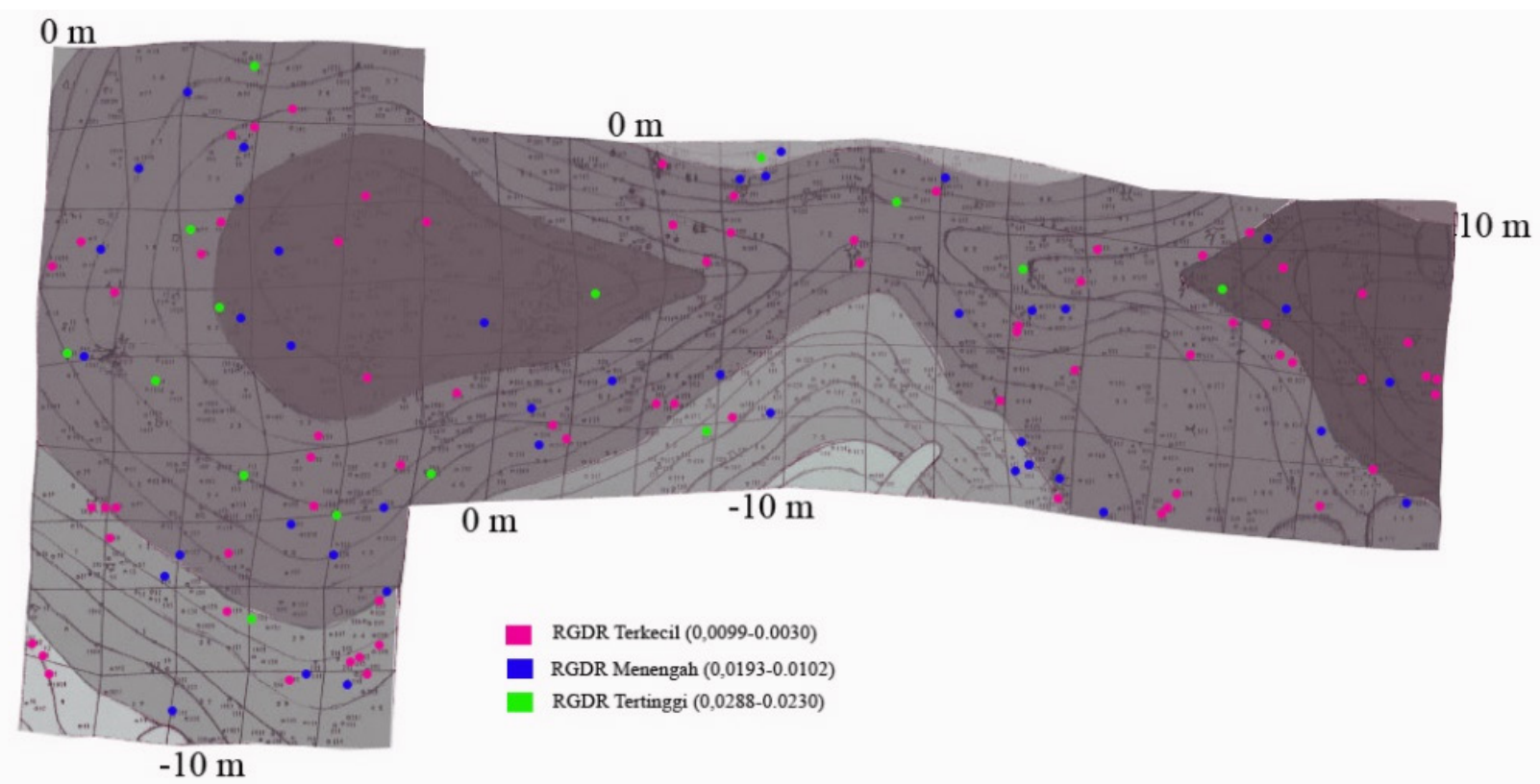

Figure 3. The map of sprouting trees distribution based on topography in permanent plots Pinang-Pinang. The difference of each contour line is 2 meters. Source: Modification of Hotta (1984).

According to sprouting distribution map (Figure 3), Bukit Pinang-Pinang Forest region was divided into three parts: The upper (610-620 $\mathrm{m}$ above sea level), The middle (600-610 $\mathrm{m}$ asl) and The bottom (590-600 m asl). Sprouting commonly was found in areas with an altitude of 600-610 m asl (Central) as many as 75 individuals; 29 species, whereas in areas with an altitude of 610- $620 \mathrm{~m}$ asl (Top) found sprouting as many as 26 individuals; 20 species and sprouting in areas with an altitude of 590-600 $\mathrm{m}$ above sea level (Bottom) found as many as 26 individuals; 18 species. Jurnal Biodjati 4(2):184-193, November 2019
The data from Mann-Whitney test showed that the altitude did not give a significant effect on RDGR individuals tree sprouting type $(p=0.99)$. It could be assumed because of the number of individuals of different species tested found in all parts of the altitude. However, the same result was also shown in the testing of individuals of the same species in all parts of the altitude, such as the type of Nephelium sp. $(\mathrm{p}=0.41)$, Nephelium juglandifolium ( $\mathrm{p}=0.94)$, Gonystylus forbesii $(\mathrm{p}=0.53)$, Mallotus subpeltatus $(\mathrm{p}=0.26)$, Sandoricum koetjape $(\mathrm{p}=0.30)$ 


\section{JURNAL BIDDJATI}

http://journal.uinsgd.ac.id/index.php/biodjati

and Syzygium sp, $(\mathrm{p}=0.54)$. It indicated that the altitude did not affect RDGR value of individual sprouting tree for 31 years because the height range in the research area was only $30 \mathrm{~m}$ above sea level with a temperature 23$26^{\circ} \mathrm{C}$. According to Belingham \& Saparrow (2009), the altitude would give effect to the distribution and growth of sprouting if range the altitude is higher than $100 \mathrm{~m}$ resulting in a drop in temperature of $0.5^{\circ} \mathrm{C}$. They found an association between sprouting growth and the altitude, which at an altitude of $560 \mathrm{~m}$ above sea level the growth only reaches $8,6 \%$, while the growth at an altitude of $1680 \mathrm{~m}$ above sea level was $15.67 \%$. It was shown from a comparison of the average and standard deviation of the maximum and minimum in each region (Figure 4).

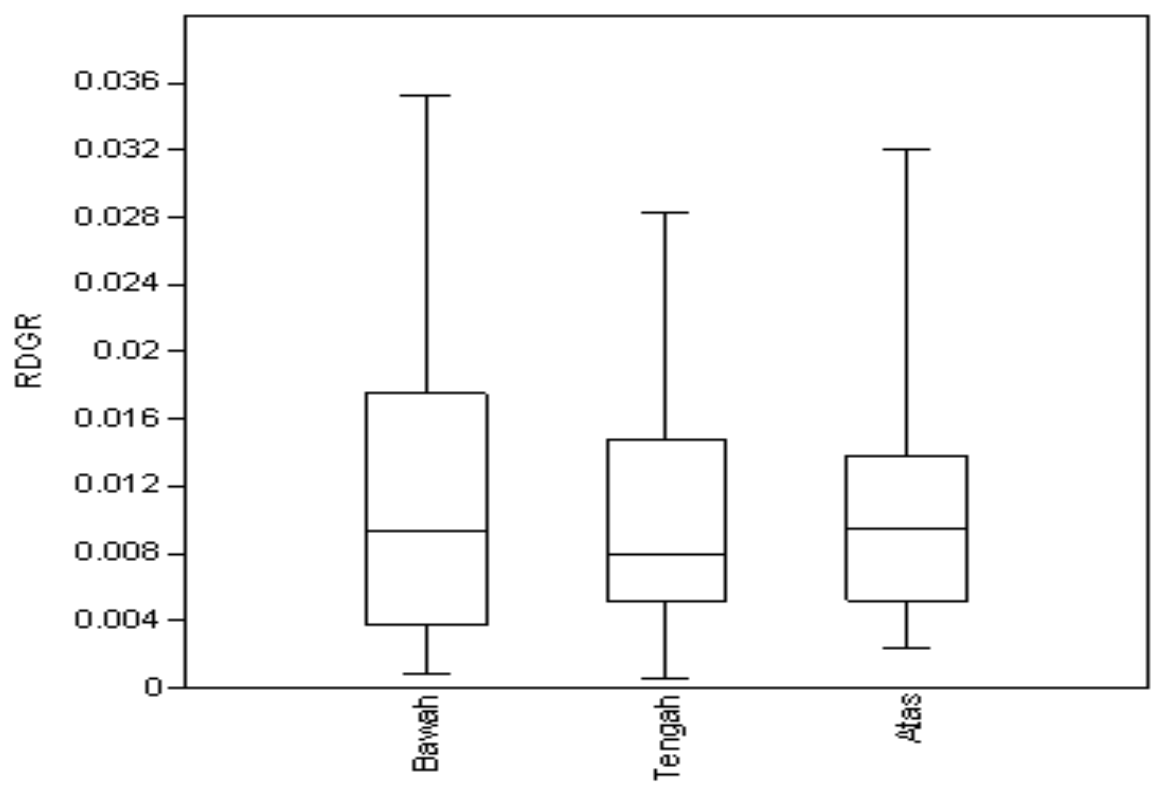

Figure 4. A RDGR of maximum, minimum, average and standard deviation values of the individual of sprouting trees type in Bukit Pinang-Pinang Forest Permanent Plots

\section{ACKNOWLEDGMENTS}

We would like to thank to Universitas Andalas and Rector of Universitas Nusa Bangsa for supporting this research. Many thanks to Mien Achmad Rifai and Nina Ariesta for giving advice in this manuscript. We also grateful for generous assistance from to Delfina Saswita, Santi Diana Putri, Apriza Hongko Putra, Adi Bejo Suwardi, Kharinnisa, Sari, Tata and all team members of Herbarium and Ecology Laboratory, Universitas Andalas.

\section{REFERENCES}

Ashish, P., Latif, K. M. \& Kumar, D. A. (2010). Effect of Stump Girth and Height on Resprouting of Rhododendron arboreum Following Disturbance in Temperate Mixed Broad Leaved Forest of Arunachal Pradesh, India. Journal of Forestry Research, 21(4), 433-438.

Balvanera, P., Pfisterer, A. B., Buchmann, N., He, J. S., Nakashizuka, T. \& Raffaelli, D. (2006). Quantifying the Evidence for Bio-diversity Effects on Ecosystem 


\section{JURNAL BIDDJATI}

http://journal.uinsgd.ac.id/index.php/biodjati

Functioning and Services. Ecol.Lett., 9, 1146-1156.

Bellingham, P. J. \& Sparrow, A. D. (2009). Multi-stemmed Trees in Montane Rain Forests: Their Frequency and Demography in Relation to Elevation, Soil Nutrients and Disturbance. Journal of Ecology, 97, 472-483.

Bond, W. J. (1994). Do Mutualisms Matter? Assessing the Impact of Pollinator/Disperser Disruption on Plant Extinctions. Philos. Trans. R. Soc. London Ser. B, 344, 83-90.

Bond, J. \& Midgley, J. J. (2001). Ecology of Sprouting in Woody Plants: the Persistence Niche. Trends In Ecology \& Evolution, 16(1), 45-51.

Brower, J. E. \& Zar, J. H. (1977). Field and Laboratory Methods for General Ecology. WMC Brown Company Publishers, Dubuque, Iowa, pp: 121-124.

Delmy, A. (1998). Fire Resistance of Tree Species in Bukit Soeharto Education Forest, East Kalimantan, Indonesia. Rehabilitation of Degraded Tropical Forest Ecosystems. Workshop proceedings. Bogor.

Gillman, L. N. \& Wright, S. D. (2006). The Influence of Productivity on the Species Richness of Plants: a Critical Assessment. Ecology, 87, 1234-1243.

Giudici, F. \& Zingg, A. (2005). Sprouting Ability and Mortality of Chestnut (Castanea sativa Mill.) After Coppicing. A case Study. Annals of Forest Science, 62, 513-523.

Halle, F., Oldeman, R. A. A. \& Tomlinson, P. B. (1978). Tropical Trees and Forests, an Architectural Analysis. Springer-Verlag. Berlin Heidelberg New York

Hotta, M. (1984). Forest Ecology and Flora of G. Gadut, Sumatra Nature Study (Botany). Kyoto University. Kyoto. Hal: 220.

Hunt, R. (1990). Basic Growth Analysis:
Plant Growth Analysis for Beginners. Unwin Hyman. London.

Irawan, B. \& Gruber, F. (2004). The Importance of Sprouting Ability in Conservation and Development of Ironwood (Eusideroxylon zwageri Teijsm. and Binn.) varieties. International Research on Food Security, Natural Resource Management and Rural development. Poverty Reduction through Research for Development and Transformation Humboldt-Universitat zu Berlin. Agricultural and Horticultural Faculty. Germany.

Kardiman, R. (2011). Struktur Tegakan Pohon Setelah 14 Tahun Penebangan Di Plot Permanen Bukit Gajabuih. Tesis. Padang: Universitas Andalas.

Kartodihardjo, H. (2001). Moratorium Penebangan Hutan. http://repository.ipb. ac.id/handle/ 123456789/41978 (downloaded 11 April 2016).

Kiyono, Y. \& Hastaniah. (2005). Patterns of Slash-and-Burn Land Use and Their Effects on Forest Succession: Swidden-land Forests in Borneo [Indonesia]. Bulletin of the Forestry and Forest Products Research Institute, 4(4), 259-282.

Lewis, M. J. \& Clarke, P. J. (2011). Ecology of Plant Resprouting: Populations to Community Responses in Fire-Prone Ecosystems. Plant Ecology.

McNaughton, S. J. \& Wolf, L. L. (1990). Ekologi Umum. Terjemahan oleh Sunaryo Pringgoseputro dan B. Sringandono. Edisi II. Gajah Mada University Press. Yogyakarta.

Mukhtar, E., Basuki, I. \& Chairul. (2012). Karakteristik Tunas Batang (sprouting) Setelah Penebangan Liar di Hutan Tropik Ulu Gadut. Biospectrum, 7(1), 57-61.

Nishimura, S., Yoneda, T., Fujii, S., Mukhtar, E., Kanzaki, M. \& Ohta, S. (2010). Sprouting Traits of Fagaceae Species in 


\section{JURNAL BIDDJATI}

http://journal.uinsgd.ac.id/index.php/biodjati

a Hill Dipterocarp Forest, Ulu Gadut, West Sumatra. Short Communication.

Ogino, K., Hotta, M., Tamin, R. \& Yoneda, T. (1984). Forest Ecology of G. Gadut area. In: M. Hotta. (ed.) Forest Ecology and Flora of G. Gadut, West Sumatra. Sumatra Nature Study. Kyoto University. pp 15-48.

Poorter, L., Kitajima, K., Mercado, P., Chubi Na, J., Melgar, I. \& Prins, H. H. T. (2010). Resprouting as a Persistence Strategy of Tropical Forest Trees: Relations with Carbohydrate Storage and Shade Tolerance. Ecology, 91(9), 2613-2627.

Putz, F. E. \& Sharitz, R. R. (1991). Hurricane Damage to Old-Growth Forest in Congaree Swamp National Monument, South Carolina, U.S.A. Canad. Journal of Forest Research, 21, 1765-1770.

Rasnovi, S. (2006). Ekologi Regenerasi Tumbuhan Berkayu Pada Sistem Agroforest Karet. Disertasi. Pascasarjana Institut Pertanian Bogor. Bogor.
Rofiadi, I. (1999). Pertambahan Tinggi Beberapa Permudaan Pohon Di Hutan Bukit Pinang-pinang. Skripsi. Universitas Andalas. Padang..

Schwilk, D. \& Ackerly, D. D. (2005). Is there a cost to resprouting? Seedling growth rate and drought tolerance in sprouting and nonsprouting Ceanothus (Rhamnaceae). American Journal of Botany, 92, 404-410.

Vesk, P. A. \& Westoby, M. (2004). Sprouting Ability Across Diverse Disturbances and Vegetation Types Worldwide. Journal of Ecology, 92, 310-320.

Whittaker, R. J. \& Heegaard, E. (2003). What is the Observed Relationship Between Species Richness and Productivity? Comment. Ecology, 84, 3384-3390 